\title{
Pengaruh Ukuran Dewan Direksi, Struktur Modal Dan Kebijakan Deviden Terhadap Nilai Perusahaan
}

\author{
Hilda Mary, Nila Pratiwi, Dewi Andromeda \\ Universitas Putra Indonesia YPTK Padang, Indonesia \\ nilapratiwi8@gmail.com
}

\begin{abstract}
The study aimed was to analyze the effect of board size (UDD), capital structure (DER), and dividend policy $(D P R)$ used as independent variables and firm value (PBV) used as the dependent variable. The data used are secondary data in the form of financial reports and annual reports from 2013 to 2017. The samples in this study were 100 companies listed on the Indonesia Stock Exchange.

The results of the study indicate that the size of the board of directors (UDD) has a positive and significant effect on the value of the company. Capital structure (DER) which shows that it has a positive and significant effect on firm's value (PBV). While Dividend Policy has a negative and significant effect on firm's value (PBV).
\end{abstract}

Keywords: value of the company, board size, capital structure and dividend policy

\section{Pendahuluan}

Dunia berbisnis yang saat ini digeluti dimana perusaahan baru makin bertambah dari waktu ke waktu. Bertambahnya jumlah perusahaan baru tentu akan mengetatkan persaingan di dalam dunia bisnis. Perusahaan-perusahaan yang bergerak di berbagai bidang tentu memiliki persaingan untuk menjadi yang terbaik dan juga mempertahankan yang sudah ada. Keadaan ini akan mendorong setiap perusahaan untuk melakukan berbagai inovasi dan strategi bisnis agar mampu bertahan dalam persaingan bisnis tersebut. Faulkender, et al (2006) perusahaan yang membuat keputusan.Semakin banyak investor yang membeli saham perusahaan maka harga saham perusahaan tersebut akan terus meningkat dan nilai perusahaan akan naik. Meningkatnya nilai perusahaan dapat membuat penilaian yang baik terhadap kinerja perusahaan maupun prospek perusahaan.

Menurut Warapsari dan Suaryana (2016) nilai perusahaan merupakan konsep penting bagi investor, karena merupakan indikator bagi pasar menilai perusahaan secara keseluruhan. Perusahaan dapat memberikan kesejahteraan bagi pemegang saham apabila nilai perusahaan meningkat. Semakin tinggi harga saham maka nilai perusahaan juga semakin meningkat. Hal tersebut sejalan dengan keinginan para pemilik perusahaan, sebab dengan nilai yang tinggi menunjukkan kesejahteraan pemegang saham juga tinggi.

Ukuran dewan merupakan jumlah personel dewan direksi dan komisaris dalam suatu perusahaan. Jumlah personel dewan akan meningkatkan kinerja perusahaan yang semakin baik. Berezinets, Ilina, dan Cherkasskaya (2018) menyatakan bahwa terdapat beberapa kekurangan dalam besarnya ukuran dewan direksi. Ukuran dewan direksi yang besar akan berakibat pada kurangnya diskusi yang berarti, sebab mengekspresikan pendapat dalam kelompok besar umumnya memakan waktu, sulit dan mengakibatkan kurangnya kekompakan pada dewan direksi. Struktur modal juga turut mempengaruhi nilai perusahaan. Struktur modal menunjukkan perbandingan antara hutang jangka panjang dengan modal sendiri. Jika dalam pendanaan perusahaan yang berasal dari modal sendiri mengalami kekurangan (defisit), maka perlu dipertimbangkan pendanaan yang berasal dari luar perusahaan, yaitu dari hutang (debt financing). Dalam pemenuhan kebutuhan pendanaan, perusahaan harus mencari alternatif-alternatif pendanaan yang efisien (Saputro, 2018). 
Struktur modal adalah salah satu pilihan kebijakan perusahaan yang paling penting yang dibuat oleh manajer suatu perusahaan. Struktur modal sangat berkaitan dengan masalah hutang dan asset perusahaan. Sehingga untuk mendapatkan harga saham yang maksimal, pada struktur modal sendiri harus bisa mencapai keseimbangan antara resiko dan return (Boateng et al., 2017).

Kebijakan dividen berhubungan dengan pembagian laba pada perusahaan yang menjadi hak bagi para pemegang sama, akan tetapi pembagian dividen kemungkinan dapat dilakukan jika laba perusahaan meningkat. Kemampuan perusahaan dalam membayarkan dividen dapat mencerminkan nilai perusahaan. Jika pembayaran dividen tinggi, maka harga saham juga tinggi yang berdampak pada tingginya nilai perusahaan begitu juga sebaliknya. Dengan demikian, kebijakan dividen merupakan salah satu keputusan yang paling penting (Prastuti dan Sudiartha, 2016).

Kebijakan dividen yaitu seberapa banyak pendapatan yang bisa dibayarkan sebagai dividen dan seberapa banyak dapat dipertahankan (Ayem dan Nugroho, 2016). Investor akan senang jika bagian dari laba bersih akan didistribusikan sebagai peningkatan dividen. Dengan demikian keputusan dividen akan mengacu pada kebijakan dividen optimal, terutama disesuaikan dengan konsep tujuan memaksimalkan nilai perusahaan. Kebijakan dividen dapat digunakan sebagai alat untuk mengurangi masalah agensi dalam perusahaan dengan mengurangi arus kas bebas dan memaksa manajemen untuk memasuki pasar modal (Al-Najjar dan Kilincarslan, 2016).

\section{Metodologi Penelitian}

\section{Populasi dan Sample}

Sample yang diambil sebanyak 100 dari 555 perusahaan manufaktur yang terdaftar di Bursa Efek Indonesia, dengan menggunakan metode random sampling.

\section{Pengukuran Variabel}

Nilai perusahaan yang tinggi akan membuat pasar percaya tidak hanya pada kinerja perusahaan saat ini namun juga pada prospek perusahaan di masa depan. Nilai perusahaan diukur dari return saham karena tujuan investor berinvestasi adalah untuk mendapatkan keuntungan atau pengembalian yang tinggi dengan tingkat risiko tertentu (Prasetia dkk, 2014).

Nilai perusahaan diukur dengan Price Book Value (PBV), Rasio ini merupakan rasio antara harga saham terhadap nilai bukunya. Perusahaan yang berjalan dengan baik umumnya mempunyai rasio PBV di atas satu, yang menunjukkan bahwa nilai pasar saham lebih besar dari nilai bukunya (Sari, 2013).

Rumus yang digunakan untuk mengukur Price to Book Value dalam penelitian ini adalah sebagai berikut:

$$
P B V=\frac{\text { Harga pasar per lembar saham }}{\text { Nilai buku per lembar saham }}
$$

Ukuran Dewan Direksi sebagai organ perusahaan bertugas dan bertanggung jawab secara legal dalam mengelola perusahaan. Ukuran dewan direksi diukur dengan menggunakan indikator jumlah anggota dewan direksi dalam suatu perusahaan (Iqbal, 2012). diformulasikan sebagai berikut :

$$
U D D=\text { Eanggota dewan direksi }
$$

Struktur modal merupakan bagian dari struktur keuangan yang mencerminkan perimbangan (absolut maupun relatif) antara keseluruhan modal eksternal (baik jangka pendek maupun jangka panjang) dengan jumlah modal sendiri (Hermuningsih, 2013). Struktur modal dalam penelitian ini diproksi melalui Debt to Equity Ratio (DER) merupakan perbandingan total utang yang dimiliki perusahaan dengan total ekuitas perusahaan. Rumus yang digunakan untuk menghitung DER adalah sebagai berikut: 


$$
D E R=\frac{\text { Debt Total }}{\text { Equity Total }}
$$

Sartini dan Purbawangsa (2014) adalah suatu ketetapan yang diambil oleh pihak manajemen perusahaan dalam membagi keuntungan perusahaan kepada para pemegang sahamnya, namun tetap memperhatikan alokasi laba ditahan sebagai dana internal untuk melakukan reinvestasi guna memaksimalkan nilai perusahaan. Kebijakan dividen dalam penelitian ini diproksikan melalui Dividend Payout Ratio (DPR). Berikut adalah rumus yang digunakan untuk menghitung Dividend Payout Ratio (DPR):

$$
\text { Dividen Payout Ratio }=\frac{\text { Dividen per share }}{\text { Earning per share }}
$$

Persamaan analisis regresi data panel dalam penelitian ini dapat dirumuskan sebagai berikut :

$$
P B V_{i t}=\alpha+\beta_{1} U D D_{i t}+\beta_{2} D E R_{i t}+
$$

\section{Keterangan :}

$\begin{array}{lll}\mathrm{PBV}= & \text { nilai perusahaan } \\ \mathrm{UDD}= & \text { ukuran dewan direksi } \\ \mathrm{DER}= & \text { struktur modal } \\ \mathrm{DPR}= & \text { kebijakan dividen } \\ \beta_{1}-\beta_{3}= & \text { Koefisien Regresi } \\ \alpha \quad= & \text { konstanta } \\ \text { it }= & \text { perusahaan } i \text { pada periode } t \\ \mathrm{e} \quad= & \text { standard error }\end{array}$

\section{Hasil Dan Pembahasan}

\section{Hasil Analisis Statistik Deskriptif}

Tabel 1

Hasil Statistik Deskriptif Data Penelitian

\begin{tabular}{lccrr}
\hline & Y_PBV & X1_UDD & X2_DER & X3_DPR \\
\hline Mean & 3,321 & 1,703 & $-0,177$ & 3,241 \\
Median & 1,760 & 1,609 & $-0,139$ & 3,405 \\
Maximum & 82,440 & 2,833 & 2,457 & 4,604 \\
Minimum & 0,030 & 0,693 & $-2,525$ & $-1,771$ \\
Std. Dev. & 6,966 & 0,423 & 0,931 & 0,889 \\
Observations & 499 & 499 & 499 & 499 \\
\hline
\end{tabular}

Catatan: Y_PBV= nilai perusahaan, UDD= ukuran dewan direksi, DER= struktur modal, dan DPR= kebijakan deviden

Hasil analisis deskriptif pada table 1 menunjukkan dari 499 observasi, data PBV berkisar antara 0,030 sampai 82,440 dengan nilai tengah (median) sebesar 1,760 dan rata-rata (mean) sebesar 3,321 dengan standar deviasi 6,966. Nilai rata-rata PBV sebesar 3,321 yang berarti bahwa rata-rata laba bersih setelah pajak (EBIT) perusahaan memiliki 3,321 kali dari jumlah asset yang dimiliki. Perusahaan yang memliki PBV terendah dalam penelitian ini adalah PT Sepatu Bata Tbk pada tahun 2013 sebesar 0,030 . Sedangkan perusahaan yang memiliki PBV tertinggi dalam penelitian ini adalah Unilever Indonesia Tbk pada tahun 2017 sebesar 82,440. Hasil analisis deskriptif pada tabel 1 menunjukkan dari 499 observasi, data UDD berkisar antara 0,693 sampai 2,833 dengan nilai tengah (median) sebesar 1,069 dan nilai rata-rata (mean) 1,703 dengan standar deviasi 0,423. Hasil analisis deskriptif pada tabel 4.2 menunjukkan dari 499 observasi, data DER berkisar antara -2,525 sampai 2,457 dengan nilai median sebesar -0,139 dan mean (rata-rata) sebesar -0,177 dengan standar deviasi 0,931.

Hasil analisis deskriptif pada tabel 1 menunjukkan dari 499 observasi, data DPR berkisar antara - 
1,771 sampai 4,604 dengan nilai median sebesar 3,405 dan mean (rata-rata) sebesar 3,241 dengan standar deviasi 0,889 .

\section{Hasil Uji Asumsi Klasik}

Pengujian asumsi klasik ini menggunakan 3 uji yakni normalitas, multikolinearitas dan heteroskedastisitas. Dari hasil uji normalitas dapat diketahui bahwa Jarque-Bera adalah sebesar 3,499 dengan probability 0,173 . Karena nilai probability sebesar $0,734>0,05$ maka dapat dikatakan bahwa residual dalam model penelitian ini telah berdistribusi normal. Hasil uji mutikolinearitas didapat bahwa masing- masing independent variable dan control variable yang digunakan telah memiliki koefisien korelasi dibawah 0,80 sehingga dapat disimpulkan bahwa masing- masing independent variable dan control variable yang digunakan terbebas dari gejala multikolinearitas. Uji heteroskedastisitas nilai probability chi-squared yang dihasilkan adalah sebesar 0,129 . Hasil yang diperoleh tersebut menunjukan bahwa nilai probability yang dihasilkan menunjukan 0,129>0,05, sehingga dapat disimpulkan bahwa seluruh variabel penelitian yang akan dibentuk kedalam model regresi telah terbebas dari gejala heteroskedastisitas.

\section{Uji Chow}

Tabel 2

Hasil Uji Chow

\begin{tabular}{lrrr}
\hline Effects Test & \multicolumn{1}{c}{ Statistic } & \multicolumn{1}{c}{ d.f. } & \multicolumn{1}{c}{ Prob. } \\
\hline Cross-section F & 39,946 & $(99,396)$ & 0,0000 \\
Cross-section Chi-square & 1195,943 & 99 & 0,0000 \\
\hline
\end{tabular}

Berdasarkan hasil uji tabel 2 dapat diketahui bahwa probability Chi-square adalah 0,000 lebih kecil dari 0,05 maka dapat disimpulkan $\mathrm{H}_{0}$ ditolak dan model Fixed Effect lebih baik dibandingkan dengan model Common Effect. Ketika model yang terpilih adalah Fixed Effect maka perlu dilakukan uji lagi, yaitu uji Hausman. Uji Hausman dilakukan untuk mengetahui apakah model Fixed Effect atau model Random Effect yang akan digunakan dalam penelitian ini.

\section{Uji Hausman}

\section{Tabel 3}

Hasil Uji Hausman

\begin{tabular}{lrrr}
\hline Test Summary & Chi-Sq. Statistic & Chi-Sq. d.f. & \multicolumn{1}{c}{ Prob. } \\
\hline Cross-section random & 5,884 & 3 & 0,117 \\
\hline
\end{tabular}

Berdasarkan hasil uji pada tabel 3 dapat diketahui bahwa probability Chi-square adalah 0,003 lebih kecil dari 0,05 maka dapat disimpulkan $\mathrm{H}_{\mathrm{a}}$ diterima dan model yang digunakan sebaiknya adalah model Fixed Effect

\section{Hasil Analisis Regresi Data Panel}

Tabel 4

Hasil Estimasi Fixed Effect Model

\begin{tabular}{|c|c|c|c|c|}
\hline Variable & Coefficient & Std. Error & t-Statistic & Prob. \\
\hline $\mathrm{C}$ & 4,922 & 2,002 & 2,457 & 0,014 \\
\hline X1_UDD & $-0,315$ & 1,141 & $-0,276$ & 0,782 \\
\hline X2_DER & 1,440 & 0,346 & 4,153 & 0,000 \\
\hline X3_DPR & $-0,249$ & 0,174 & $-1,430$ & 0,153 \\
\hline
\end{tabular}

Catatan: UDD $=$ ukuran dewan direksi, $\mathrm{DER}=$ struktur modal, dan $\mathrm{DPR}=$ kebijakan deviden 

berikut :

Berdasarkan model estimasi yang terpilih, diperoleh persamaan model regresi data panel sebagai

$$
P B V_{i t}=4,992-0,315_{i t}+1,440_{i t}-0,249_{i t}
$$

1. Nilai konstanta a sebesar 4,992 artinya jika variabel UDD, DER, dan DPR pada observasi ke i dan periode ke $t$ dianggap konstan (tetap atau tidak ada perubahan) maka PBV sebesar $4,992$.

2. Nilai koefisien $\beta_{1}$ sebesar $-0,315$ artinya jika UDD pada observasi ke $\mathrm{i}$ dan periode ke $\mathrm{t}$ meningkat sebesar satu (1) satuan, maka PBV menurun sebesar 0,315 dengan asumsi variabel DER dan DPR tetap konstan.

3. Nilai koefisien $\beta_{2}$ sebesar 1,440 artinya jika nilai DER pada observasi ke $\mathrm{i}$ dan periode ke $\mathrm{t}$ meningkat sebesar satu (1) satuan, maka PBV naik sebesar 1,440 dengan asumsi variabel UDD dan DPR tetap konstan.

4. Nilai koefisien $\beta_{3}$ sebesar -0,249 artinya jika nilai DPR pada observasi ke $\mathrm{i}$ dan periode ke $\mathrm{t}$ meningkat sebesar satu (1) satuan, maka PBV turun sebesar 0,249 dengan asumsi variabel UDD dan DER tetap konstan.

\section{Hasil Pengujian Koefisien Determinasi $\left(\mathbf{R}^{2}\right)$}

Koefisien determinasi $\left(\mathrm{R}^{2}\right)$ menunjukkan proporsi yang diterangkan oleh independent variable dalam model terhadap dependent variable dan control variable, sisanya dijelaskann oleh variabel lain yang tidak dimasukkan dalam model, formulasi model yang keliru dan kesalahan eksperimen. Hasil uji koefisien determinasi dapat dilihat pada tabel seperti berikut:

Tabel 5

Hasil Uji Koefisien Determinasi $\left(\mathbf{R}^{2}\right)$

\begin{tabular}{lr}
\hline R-squared & 0,911 \\
Adjusted R-squared & 0,888 \\
\hline
\end{tabular}

Berdasarkan Tabel 5 menunjukkan bahwa nilai koefisien determinasi yang dihasilkan dalam pengujian Adjusted $R$-squared bernilai 0,888 . Hasil yang diperoleh menunjukkan bahwa variabel uksuran dewan direksi (UDD), struktur modal (DER) dan kebijakan dividen (DPR) mampu memberikan kontribusi dalam mempengaruhi nilai perusahaan sebesar $88,80 \%$ sedangkan sisanya $11,20 \%$ (100\% - 88,80\%) lagi dipengaruhi oleh variabel lain yang tidak dimasukkan dalam model seperti ukuran dewan direksi, struktur modal, dan kebijakan dividen.

\section{Hasil Pengujian Hipotesis Secara Simultan (Uji F)}

Uji ini bertujuan untuk mengetahui apakah independent variable secara bersama-sama berpengaruh terhadap dependent variable dan juga untuk mengetahui ketepatan pemilihan variabel yang akan dibentuk kedalam sebuah model regrasi maka dilakukan pengujian F-statistik. Hasil uji F dapat dilihat pada tabel dibawah ini :

\section{Tabel 6}

Hasil Uji F-Statistk

\begin{tabular}{lc}
\hline F-statistic & 39,956 \\
Prob(F-Statistic) & 0,000 \\
\hline
\end{tabular}

Berdasarkan tabel 6 menunjukkan nilai F-statistik sebesar 39,956 dan probability sebesar 0,000 dengan tingkat kesalahan yang digunakan sebesar 0,05 . Hasil yang diperoleh menunjukkan bahwa nilai probability yang dihasilkan sebesar $0,000<0,05$ maka keputusannya adalah bahwa ukuran dewan direksi (UDD), struktur modal (DER) dan kebijakan dividen (DPR) berpengaruh positif 
dan signifikan secara bersama-sama terhadap nilai perusahaan pada perusahaan manufaktur yang terdaftar di Bursa Efek Indonesia pada tahun 2013-2017.

\section{Hasil Pengujian Hipotesis Secara Parsial (Uji t)}

Uji t digunakan untuk menguji pengaruh independent variable secara parsial terhadap variable dependent. Pengujian ini dilakukan dengan ketentuan:

1) Apabila probability thitung < 0,05, maka Ho ditolak dan Ha diterima

2) Apabila probability thitung $>0,05$, maka Ho diterima dan Ha ditolak

Berdasarkan tabel 4, Pengaruh Variabel Ukuran Dewan Direksi (UDD), Struktur Modal (DER), dan Kebijakan Dividen (DPR) dapat diuji sebagai berikut:

a. Pengaruh Ukuran Dewan Direksi terhadap Nilai Perusahaan

Hasil analisis menunjukkan bahwa Ukuran Dewan Direksi memiliki nilai koefisien regresi sebesar $-0,315$ dan tstatistic sebesar -0,276 dengan nilai probability sebesar 0,782 lebih besar dari 0,05 atau $(0,782>0,05)$ maka dapat disimpulkan bahwa variabel ukuran dewan direksi (UDD) secara parsial berpengaruh negatif dan tidak signifikan terhadap nilai perusahaan pada perusahaan manufaktur yang terdaftar di Bursa Efek Indonesia pada tahun 2013-2017. Sehingga Ho ditolak dan Ha diterima.

b. Pengaruh Struktur Modal terhadap Nilai Perusahaan

Hasil analisis menunjukkan bahwa Struktur Modal (DER) memiliki nilai koefisien regresi sebesar 1,440 dan tstatistic sebesar 4,153 dengan nilai probability sebesar 0,000 lebih kecil dari 0,05 atau $(0,000<0,05)$ maka dapat disimpulkan bahwa variabel struktur modal secara parsial berpengaruh positif dan signifikan terhadap nilai perusahaan pada perusahaan manufaktur yang terdaftar di Bursa Efek Indonesia pada tahun 2013-2017. Sehingga Ho diterima dan Ha ditolak.

c. Pengaruh Kebijakan Dividen terhadap Nilai Perusahaan

Hasil analisis menunjukkan bahwa kebijakan dividen (DPR) memiliki nilai koefisien regresi sebesar -0,249 dan tstatistic sebesar -1,430 dengan nilai probability sebesar 0,153 lebih besar dari 0,05 atau $(0,153>0,05)$ maka dapat disimpulkan bahwa variabel kebijakan dividen berpeng aruh negatif dan tidak signifikan terhadap nilai perusahaan pada perusahaan manufaktur yang terdaftar di Bursa Efek Indonesia pada tahun 2013-2017. Sehingga Ho ditolak dan Ha diterima.

\section{Kesimpulan}

Berdasarkan kepada analisis dengan pembahasan hasil pengujian hipotesis maka dapat diajukan beberapa kesimpulan penting yang merupakan inti jawaban dari masalah yang dibahas didalam penelitian ini, yaitu:

1. Ukuran dewan direksi yang diproksikan dengan UDD secara parsial berpengaruh negatif dan tidak signifikan terhadap nilai perusahaan.

2. Struktur modal yang diproksikan dengan DER secara parsial berpengaruh positif dan signifikan terhadap nilai perusahaan. Hasil pengujian pengaruh struktur modal (DER) terhadap nilai perusahaan (PBV) konsisten dengan uraian teori dan hipotesis yang diajukan. Dimana struktur modal (DER) berpengaruh positif terhadap nilai perusahaan (PBV). Semakin tinggi struktur modal (DER) maka semakin tinggi pula nilai perusahaan (PBV) yang akan diperoleh perusahaan bersangkutan.

3. Kebijakan dividen secara parsial berpengaruh negatif dan tidak signifikan terhadap nilai perusahaan. 


\section{DAFTAR PUSTAKA}

Amar, B. A., Olfa, B. S., And Anis, J. (2018) "Do discretionary accruals affect firms' corporate dividend policy, Evidence from France", Journal of Financial Reporting and Accounting, Vol. 16 Issue: 2, pp.333-347.

Ayem, S., \& Nugroho, R. (2016). Pengaruh Profitabilitas, Struktur Modal, Kebijakan Dividen, dan Keputusan Investasi Terhadap Nilai Perusahaan (Studi Kasus Perusahaan Manufaktur Yang Go Publik Di Bursa Efek Indonesia) Periode 2010-2014. Jurnal Akuntansi, Vol.4, No. 1, Hal.31-39.

Alias, et al (2014). Board structure, capital structure and dividend per share: is there interaction effect?. Universiti Kebangsaaan Malaysia, Vol. 7(No.1).

Assyaari, dkk (2018). Pengaruh Kebijakan Pendanaan, Kebijakan Dividen dan Profitabilitas Terhadap Nilai Perusahaan (Studi Empiris pada Perusahaan Manufaktur yang Terdaftar di Bursa Efek Indonesia Periode 2012-2015). Jurnal Ekonomi dan Bisnis. Vol.5, No.1, pp:628.

Dawar varun, (2014). Agency theory, capital structure and firm performance: some Indian evidence. Managerial Finance, Vol. 40 Issue: 12, pp.1190-1206.

Dwi Payana \& wiksuna 2014. Analisis Pengaruh Kebijakan Utang, Kebijakan Dividen, dan Kinerja Keuangan Terhadap Nilai Perusahaan pada Perusahaan Manufaktur yang Terdaftar di Bursa Efek Indonesia Tahun 2009-2011. Jurnal Udinus: 1-13 Fahmi, 1. (2014). Manajemen Keuangan Perusahaan Dan Pasar Modal. Jakarta: Mitra Wacana Media.

Harmono. (2017). Manajemen Keuangan Berbasis Balanced. Jakarta: Pt Bumi Angkasa Raya.

Harmono. (2015). Manajemen Keuangan Berbasis Balanced. Jakarta: Pt Bumi Angkasa Raya.

Hermuningsih, S. (2013). Pengaruh Profitabilitas, Growth Opportunity, Struktur Modal Terhadap Nilai Perusahaan Pada Perusahaan Publik Di Indonesia. Bulletin Of Monetary Economics And Banking (Buletin Ekonomi Moneter Dan Perbankan), 16(2), 127-148.

Hemastuti, C. P., \& Hermanto, S. B. (2014a). Pengaruh Profitabilitas, Kebijakan Dividen, Kebijakan Hutang, Keputusan Investasi Dan Kepemilikan Insider Terhadap Nilai Perusahaan. Jurnal Ilmu \& Riset Akuntansi, 3(4), 1-15.

Hemastuti, C. P., \& Hermanto, S. B. (2014b). Pengaruh Profitabilitas, Kebijakan Dividen, Kebijakan Hutang, Keputusan Investasi Dan Kepemilikan Insider Terhadap Nilai Perusahaan. Jurnal Ilmu \& Riset Akuntansi, Vol.3(No.4), 1-15.

Jayanti, Fitri Dwi. (2018). Pengaruh Profitabilitas, Struktur Modal, Likuiditas, dan Ukuran Perusahaan Terhadap Nilai Perusahaan. Jurnal Ekonomika dan Bisnis. Vol.3 , No.2, pp:3444.

Jensen, M. C and Meckling, W.H. (1976). Theory of the Firm : Managerial Behavior, Agency Costs and Ownership Structure. Journal of Financial Economics, Oktober, 1976, V. 3, No. 4, pp. 305-360.

Kasmir. (2015). Analisis Laporan Keuangan. Jakarta: Pt Rajagravindo Persada.

Kurniawan, A.P., dan Mertha, I.M. "Kinerja Keuangan Sebagai Pemediasi Pengaruh Intensitas Research And Development Dan Aset Tidak Berwujud Pada Nilai Perusahaan". E-Jurnal Akuntansi Universitas Udayana. Vol 14.1. Januari 2016. 723-750, ISSN: 2303-8556. 2016.

Martha Lidya, dkk (2018). Profitabilitas Dan Kebijakan Dividen Terhadap Nilai Perusahaan”. Jurnal Benefita, 3(2) Juli 2018 (227-238).

Monica, L., Muchdie, Uzair A. (2017). Struktur modal, dan Keputusan Investasi Terhadap Nilai Perusahaan. Jurnal Ekonomi dan Bisnis. Vol. 1, No. 2, Hal 221-230. p-ISSN: 2549-5658 eISSN: 2549-7243.

Pantow, M. S. R., Murni, S., dan Trang, 1. (2015). Analisis Pertumbuhan Penjualan, Ukuran Perusahaan, Return On Asset, Dan Struktur Modal Terhadap Nilai Perusahaan Yang Tercatat Di Indeks Lq 45. Jurnal Riset Ekonomi, Manajemen, Bisnis Dan Akuntansi, 3(1). Hal 961-971.

Prastuti, N. K. R., \& Sudiartha, I. G. M. (2016). Pengaruh Struktur Modal, Kebijakan Dividen, dan 
Ukuran Perusahaan Terhadap Nilai Perusahaan Pada Perusahaan Manufaktur. E-Jurnal Manajemen Unud, 5(3), 1572-1598.

Puspita (2016). Pengaruh Struktur Modal dan Keputusan Investasi Terhadap Profitabilitas dan Nilai Perusahaan. Jurnal Ilmu Dan Riset Manajemen, 4(2), 1-17.

Reddy, K., And Stuart L. (2016). The relationship between ownership structure, capital structure and corporate governance practices: A case study of co-operatives and mutuals in New Zealand. International Journal of Managerial Finance, Vol. 10 Issue: 4, pp.511-536

Sari, Ardiana (2016). Pengaruh Keputusan Investasi, Keputusan Pendanaan dan Kebijakan Dividen Terhadap Nilai Perusahaan. Jurnal Analisis Manajemen, 2(2), 1-7.

Saputro (2018). Pengaruh Keputusan Investasi, Kebijakan Dividen, Serta Keputusan Pendanaan Terhadap Nilai Perusahaan Manufaktur Di Bursa Efek Indonesia. Jurnal Manajemen, Strategi Bisnis Dan Kewirausahaan, 8(2), 81-90.

Senata, M. (2016). Pengaruh Kebijakan Dividen Tehadap Nilai Perusahaan Tercatat pada Indeks LQ45. Jurnal Wira Ekonomi Mikroskil, 6, 73-84.

Sugiyono, (2016). Metodologi Penelitian. Bandung: Alfabet

Warapsari \& Suaryana. 2016. Pengaruh Kebijakan Financial Leverage dan Kebijakan Dividen Terhadap Nilai Perusahaan Pada Perusahaan Pertambangan yang Terdaftar di Bursa Efek Indonesia (BEI). Skripsi. Universitas Esa Unggul. 